\title{
From customer value to repurchase intentions and recommendations
}

\section{Abstract:}

Purpose - The paper aims to fill the gap in the literature in relation to the determinants of customer value within the research and development (R\&D) industry and word-of-mouth. It investigates whether context specific variables, such as organizational type and contract length, change customer value evaluations and the value - intention to repurchase recommend system.

Design/methodology/approach - A survey of Australian customers of a research and development service organization was conducted. Structural equation modelling was used to develop a model investigating factors that affect customer value, intent to re-purchase, and word-of-mouth/recommendation.

Findings - Relationship benefits, service benefits and sacrifice all had a significant influence on customer value. Efficient use of time is crucial for sacrifice evaluation. Relationship benefits were larger for government organizations than private organizations. Importance of value to recommend the organisation to others was higher for longer contracts and government customers.

Research limitation/implications - Results show that R\&D organizations need to concentrate on both the technical service/ science aspects and the relationship aspects in their contracts. Government institutions tended to emphasize the relationship benefits while private businesses considered service benefits, relationship benefits and sacrifice nearly equal in their determination of value. Intent to contract $R \& D$ organization for further work and the willingness to recommend it to others as a highly specialised and competent service provider seem to be higher for government customers and longer contracts.

Originality/ Value - This paper investigates customer value in a little researched industry, R\&D. The findings are relevant for similar professional business-to-business services.

\section{Keywords:}

R\&D industry, value, benefits, sacrifices, intent to repurchase, word of mouth 


\section{Introduction}

Research and development (R\&D) is a necessary engine for supporting economic growth and developing knowledge based economies (Gupta and Wilemon, 1996; Hirons, Simon and Simon, 1998; Plewa and Quester, 2006). Therefore, improving R\&D performance is critical for economies to grow and strengthen. Collaboration between government, R\&D organizations, and private enterprises is resulting in an increased focus on managing $R \& D$ relationships rather than considering performance measurements based solely on patent numbers or technology transfer initiatives (Hirons et al, 1998; Plewa and Quester, 2006). Yet, there is still a lack of research investigating how improving R\&D business relationships affects value offerings (Plewa and Quester, 2006; Hirons et al., 1998; GarrettJones, Turpin, Burns, and Diment, 2005). This topic is important given the necessity of improving $\mathrm{R} \& \mathrm{D}$ outcomes and the lack of research into R\&D business relationships'.

The R\&D industry is made up of a variety of organizational forms (Garrett-Jones et al., 2005) with different researchers focusing on different forms: universities (Garrett-Jones et al., 2005), university-industry alliances (Plewa and Quester, 2006), divisions within innovative private organizations (Gupta and Wilemon, 1996; Pike, Roos and Marr, 2005; Hirons et al., 1998), government departments (Garrett-Jones et al., 2005) and semiprivatized government organizations (Pike et al., 2005). R\&D is a complex high-velocity knowledge intensive service industry (Grewal, Gotlieb, and Marmonstein, 2000) where development of new knowledge benefits both society at large (public good) and R\&D customers making benefits difficult to measure (Osawa and Yamasaki, 2005; Skaates and Cova, 2005). 
This paper focuses on a large multidisciplinary Australian agency conducting scientific research and involved in a number of joint ventures. The organization has undergone a dramatic overhaul during the semi-privatization process (that has a mixed funding from government and private organizations) and now needs to consider how their offerings deliver value, instead of just excellent science.

The Marketing Science Institute highlights customer value as a marketing research priority (Lindgreen and Wynstra, 2005). Currently, research tends to focus on investigating value within B2C contexts rather than B2B (Lindgreen and Wynstra, 2005), let alone within an R\&D context (Plewa and Quester, 2006). Research into the role of value within complex services is currently lacking and further investigations are required (Cova and Salle, 2007). In addition, changes in $R \& D$ operations, requiring funds from private sources, imply that $\mathrm{R} \& \mathrm{D}$ organizations need to pro-actively promote their excellence and custom-tailored research solutions to a larger audience. Referencing/recommendations become essential given the high risk nature of R\&D services (Salminen and Möller, 2006, p. 23). Despite the essential role referencing plays in complex services and project marketing (Dawes, Dowling and Patterson, 1991; Salminen and Möller, 2004; Cova and Salle, 2007), research into how current business relationships affect a customer's intentions to recommend a service provider to others is scarce (Money, Gilly, and Graham, 1998; Harrison-Walker, 2001; Salminen and Möller, 2004). Also previous research has associated recommending intentions to commitment (Harrison-Walker, 2001) and satisfaction (Money et al., 1998), not value.

This research furthers our knowledge by contributing to both of the above gaps. Specifically, the research objectives are: 
- extending our understanding of determinants of customer value within complex B2B services, and

- linking value to re-purchase intentions and willingness to recommend to others.

In addition, this research explores differences in the triplet value - intent to repurchaseword-of-mouth for different types of customers and durations of relationships.

The paper begins with a discussion on customer value, followed by the importance of recommendations to others, elaboration of the propositions and model development. These sections are followed by a discussion on the data collection and on the analysis using structural equation modelling. The results of the research are presented with a discussion on the academic and managerial implications. The paper concludes with limitations and directions for future research.

\section{Concepts}

\subsection{Customer Value}

Understanding a customer's value position is an important management tool for improving customer service delivery (Ravald and Grönroos, 1996; Lindgreen and Wynstra, 2005; Kordupleski, 2003). Yet, the value construct is complex (Ismail and Khatibi, 2004) and its use within the literature varies considerably (Lin, Sher, and Shih, 2005). Value is described as a 'trade-off' between overall benefits gained and sacrifices made by the customer (Ravald and Grönroos, 1996; Flint, Woodruff, and Gardial, 1997; Ziethaml, 1988; Lapierre, 2000; Teas and Agarwal, 2000; Woodall, 2003; Lin et al., 2005). Benefits gained include quality of the products and services offered and the benefits from the relationship (Ravald and Grönroos, 1996; Flint et al., 1997; Lapierre, 2000; Lindgreen and Wynstra, 2005). 
Sacrifices include monetary sacrifices such as direct costs, acquisition costs, and operation costs (Cannon and Homburg, 2001), and non-monetary sacrifices such as time, effort, and energy invested (Ravald and Grönroos, 1996; Lapierre, 2000). The underlying principle is to achieve the required functions/ service at the lowest possible cost without lowering quality (Flint et al., 1997; Fong, Shen and Cheng, 2001).

\section{Benefits}

Benefits are obtained directly through the product or service acquired and indirectly through the business relationship (Ravald and Grönroos, 1996; Walter, Ritter, and Gemünden, 2001; Lapierre, 2000; Möller and Törrönen, 2003; Lindgreen and Wynstra, 2005). Indirect supplier value benefits have been categorized as innovation function, market function, scout function and access function. Direct value benefits include profit function, volume function, and safeguard function (Walter et al., 2001; Möller and Törrönen, 2003). This categorization system is not used further as it focuses on suppliers rather than customers. Sweeney and Webb (2007) categorized indirect benefits as social, psychological, and direct benefits as functional. Lapierre (2000) categorizes direct benefits as product benefits, service benefits, and relationship benefits, where the indirect benefits fall into the relationship benefit category. This research follows the categories outlined by Lapierre (2000) with direct benefits aligning to service benefits and indirect benefits aligning with relationship benefits.

Lapierre (2000) conceptualises direct benefits along seven dimensions: alternative solutions, product quality, product customisation, responsiveness, flexibility, reliability, and technical competence. Within a R\&D context direct benefits previously focused on are the number of patents and technology transfer with limited results (Hirons et al., 1998; 
Plewa and Quester, 2006). Within the context of projects service benefits focus on project management outcomes is aimed at reducing process redundancies through the systemization of project offerings (Cova and Salle, 2007; Skaates, Tikkanen and Lindblom, 2002).

Relationship benefits are a key aspect that customers consider in the overall value of the offering (Ravald and Grönroos, 1996; Lapierre, 2000; Håkansson and Snehota, 2000; Wathne, Biong, and Heide, 2001; Lindgreen and Wynstra, 2005). In fact, Cova and Salle (2007) report that the ability of personnel to develop strategic relations is a key success factor in project marketing. Most conceptualizations of relationship benefits include constructs such as: trust, commitment, conflict and communication. Håkansson and Snehota (2000) also include technical benefits similar to the service/product benefits of Lapierre (2000). Lapierre (2000) incorporates suppliers' image within relationship benefits which is an important component within the R\&D industry (Stuart, 1998). Key marketing tools used for developing a good image is referencing and word of mouth, particularly within complex service industries (Harrison-Walker, 2001; Salminen and Möller, 2004).

\section{Sacrifice}

The relationship between sacrifice and value is complex as sacrifice is seen as having a greater negative impact on value compared to the positive impact of benefits (Ravald and Grönroos, 1996). Lapierre (2000) has three items measuring sacrifice: price, time/effort/energy and conflict, with price being the strongest indicator of sacrifice. Time as sacrifice has been found a significant element of value (Kothari and Lackner, 2006) and a determinant for customers' repurchase intent (Kumar, 2002). In other research, price or 
monetary sacrifice is often used as the sole determinant of sacrifice (Teas and Agarwal, 2000; Murphy, 2002).

An increase in price results in an increase in monetary sacrifice for the customer, thus impacting negatively on value to the customer (Teas and Agarwal, 2000). However, the overall effect of price on value will depend on the relative relationships of benefits and sacrifice on value.

Price has been used as a cue for the likely perceptions of the quality of the product/service being offered (Voss, Parasuraman, and Grewal, 1998), thus having an indirect positive affect on value (Teas and Agarwal, 2000). Lapierre (2000) finds that the affect of price is context specific and varies across industries. For example, within distribution, price has no affect on perceived benefits, while within financial services price has a strong affect on perceived benefits provided. Within the R\&D industry communicating quality without correlating it to price is difficult (Caru and Cugini, 1999). Traditional scientific organizations have evolved from a cost plus pricing structure which has no connection to the value they offer the customer. As research organizations begin to operate in a deregulated competitive environment, $R \& D$ organizations need to focus on price as a cue for value. The focus on price rather than costs allows research organizations to enter niche markets and maximize their returns based on image (Stuart, 1998).

\subsection{Intent to repurchase}

Customers' repurchase intent depends on the value obtained in their previous transactions (Wathne et al., 2001; Kaynak, 2003; Bolton, Kannan, and Bramlett, 2000) such as: appropriate performance criteria (benefits), competition, and cost considerations (Kumar, 2002). Future purchase intentions also have a relationship with customer satisfaction 
(Patterson, Johnston, and Spreng, 1997; Durvasula, Lysonski, Mehta, and Tang, 2004). Overall, customers evaluate future purchase intentions based on the value obtained from previous episodes/contacts, with relationship benefits being a proxy for expectations of future benefits.

\subsection{Recommending to Others}

Customers use "word of mouth", referrals and referencing as important information sources to evaluate suppliers of complex business services (Dawes et al., 1991). Yet, determining what makes current customers willing to provide such information is a topic area that needs further research (File, Cermak, and Prince 1994; Harrison-Walker, 2001; Buttle, 1998).

Salminen and Möller (2004) made a direct link between word-of-mouth (WOM) and references. Referencing is when suppliers provide new customers a list of previous customers with whom they can contact as a tool to reduce the perceived risk in dealing with the service provider (Salminen and Möller, 2004). Referencing improves the supplier's credibility and image by convincing new customers that the supplier has the technical competence to perform the tasks required (Buttle, 1998). Reference information is "evaluations in written or oral form about the suppliers' performance from its existing or former customer's viewpoint" (Salminen and Möller, 2004, p.135). Referencing has been highlighted as a function of market value (Walter et al., 2001; Möller and Törrönen, 2003). Word-of-mouth is evaluation in oral form about a suppliers' performance (Buttle, 1998). Output WOM is positively associated with satisfaction (File et al., 1994) and commitment (Harrison-Walker, 2001) with only limited research linking it to value (see Hartline and 
Jones, 1996), even though value is communicated through WOM communications (Mangold, Miller and Brockway, 1999). Within the hospitality industry, Harline and Jones (1996) reports that value positively influences recommendation intentions.

This paper uses interchangeably the terms recommendation, word-of-mouth, and referencing.

\section{Model Development}

The conceptual model is shown in Figure 1 and the literature-based research propositions are presented in Table 1. The model applies reflective measures for benefits and sacrifices and tests the moderating effect of customer organizational type and contract length.

\section{Figure 1 Conceptual Model}




Table 1 Research propositions

\begin{tabular}{|c|c|c|}
\hline ID & Propositions & Literature supporting the proposition \\
\hline $\mathrm{P} 1$ & $\begin{array}{l}\text { Service Benefits are positively related to } \\
\text { Value }\end{array}$ & $\begin{array}{l}\text { Teas and Agarwal (2000); Dodds, Monroe, and Grewal } \\
\text { (1991); Ravald and Grönroos (1996); Lapierre (2000); } \\
\text { Woodall (2003); Kordupleski (2003) found positive }\end{array}$ \\
\hline $\mathrm{P} 2$ & $\begin{array}{l}\text { Relationship Benefits are positively related to } \\
\text { Value }\end{array}$ & linkage between benefits and value \\
\hline P3 & $\begin{array}{l}\text { Service and Relationship Benefits are related } \\
\text { to each other }\end{array}$ & $\begin{array}{l}\text { Sweeney and Webb (2007) found strong correlations } \\
(0.53-0.58) \text { between their three benefit categories; } \\
\text { Lapierre }(2000)\end{array}$ \\
\hline $\mathrm{P} 4 \mathrm{a}$ & $\begin{array}{l}\text { Service Benefits are positively related to } \\
\text { Monetary Sacrifice }\end{array}$ & \\
\hline $\mathrm{P} 4 \mathrm{a}$ & $\begin{array}{l}\text { Relationship Benefits are positively related to } \\
\text { Monetary Sacrifice }\end{array}$ & $\begin{array}{l}\text { Voss, Parasuraman, and Grewal (1998); Teas and } \\
\text { Agarwal (2000) }\end{array}$ \\
\hline P5 & $\begin{array}{l}\text { Monetary Sacrifice is negatively related to } \\
\text { Value }\end{array}$ & $\begin{array}{l}\text { Teas and Agarwal (2000); Dodds, Monroe, and Grewal } \\
\text { (1991); Ravald and Grönroos (1996); Murphy (2000); } \\
\text { Fong, Shen, and Cheng (2001); Kumar (2002); Kothari } \\
\text { and Lackner (2006) found negative relation between } \\
\text { sacrifice/cost and value }\end{array}$ \\
\hline P6 & $\begin{array}{l}\text { Value is positively related to Re-purchase } \\
\text { Intentions }\end{array}$ & $\begin{array}{l}\text { Wathne, biong, and Heide (2001); Kaynak (2003); } \\
\text { Bolton, Kannan, and Bramlett (2000); Kumar (2002) }\end{array}$ \\
\hline P7 & $\begin{array}{l}\text { Value is positively related to } \\
\text { Recommendation to others }\end{array}$ & Hartline and Jones (1996) \\
\hline P8 & $\begin{array}{l}\text { Re-purchase Intentions are positively related } \\
\text { to Recommendation to others }\end{array}$ & Kumar (2002) \\
\hline P9a & $\begin{array}{l}\text { Organizational type impacts differently on all } \\
\text { relationships within the model }\end{array}$ & Anderson and Narus (1999) \\
\hline $\mathrm{P} 9 \mathrm{~b}$ & $\begin{array}{l}\text { Contract length impacts differently on all } \\
\text { relationships within the model }\end{array}$ & $\begin{array}{l}\text { Anderson and Weitz (1989); Morgan and Hunt (1994); } \\
\text { Verhoef, Franses, and Hoekstra (2002) }\end{array}$ \\
\hline
\end{tabular}

\subsection{Value determinants}

Value is a multidisciplinary term having large variations in the connotation, potential sources or determinants of value. Woodall (2003, p.6) highlighted that 'eighteen different names for similarly-described, demand-side notions of value were found' and that 'authors would occasionally use different names within the same paper'. Woodall (2003) also found that value was described as either 'customer value', 'perceived value' or 'value'. This 
paper uses the term 'value' in lieu of perceived value as: (1) empirical data was collected six months post project completion indicating that the customer had finished consuming the offering and thus could determine whether value was actually achieved; and (2) many of the relationships continued over a longer time period (i.e., new projects were awarded after completion of previous projects) allowing time for the customer to assess value creation.

With respect to measurement, there is a wide spectrum of approaches, with some research using a uni-dimensional measure of value, while others include formative and/or reflective items for value construct (Lin et al., 2005). Lin et al. (2005) and Ulaga and Eggert (2006) support empirical research relying on formative multidimensional scales of relationship value. However, Ulaga and Eggert (2006) suggest that reflective measures are appropriate if value is considered a unidimensional abstract construct. In this research the formative structure was not confirmed for benefits and sacrifices, therefore, we considered them as reflective antecedents of value (seen as a formative construct), consistent with Lapierre (2000), Lin et al. (2005), and Ulaga and Eggert (2006). As a departure from Lapierre (2000), who highlighted three categories of benefits (product, service, and relation), this research merged into a single construct service and product benefits, given the specificity of the R\&D industry.

Another aspect of research into value is whether to measure expectations (perceptions of benefits prior to consumption); post-purchase evaluations, or the gap between expectations and benefits. Expectations are difficult to develop when business services involve a high level of complexity in the decision making process (Patterson et al., 1997; Skaates and Cova, 2005), which would be the case within the R\&D industry. Customer perceptions 
post-purchase also explain more of the variation in service quality, negating the requirement to measure the gap (expectations and performance) (Cronin and Taylor, 1992). Therefore, this research measures post-performance indicators of benefits and sacrifices.

\subsection{Re-purchase Intention and Recommendations to Others}

The decision by customers to re-purchase from the same service provider depends on their past experiences (Wathne et al., 2001); their perceptions of value from previous service encounters (Bolton et al, 2000); and expectations of the future business relationship. Improvements in benefits will result in more satisfied customers with greater loyalty and an enhanced competitive position (Kaynak, 2003).

Durvasula et al. (2004) investigated separately the connection between perceived value and "post-purchase behaviours (behavioural and attitudinal loyalty) measured by repurchase intentions and willingness to recommend to others" (p.319), without linking intention to WOM. This research uses a single item to measure recommendations similar to File et al., (1994) and Durvasula et al. (2004).

\subsection{Moderators: Customer Organizational Type and Length of contract}

Due to changes in funding arrangements organizational type is split into two categories: government and private institutions. Private businesses are likely to be smaller in size and contract the professional service provider for smaller contracts (both $\$$ value and duration), usually consulting services, while government institutions contracts are of larger scope, often strategic research with large societal returns. Therefore, the type of customer is 
expected to impact on the nature of the work and on the business relationship development. Inclusion of organizational type as a moderating variable allows exploration not only of whether value has different determination for different customer types, but also on how the paths to repurchase intent and WOM are drawn for government and private customers.

As the R\&D environment is highly competitive, consideration of how contract length affects value generation is beneficial. Previous research has pointed out that trust develops over an extended time period and is an important component of relationship benefits (Anderson and Weitz, 1989; Morgan and Hunt, 1994; Håkansson and Snehota, 2000). Other research highlighted that relationship age affects commitment, rather than trust (Verhoef, Franses and Hoekstra, 2002), and consequently the future of the relationship between the R\&D supplier and the customer. Therefore, the inclusion of contract length as another moderating variable allows the research to explore the implications of long term (LT) vs short term (ST) contracts.

\section{Methodology and data}

The context of this research is the Australian R\&D industry, specifically a large multidisciplinary agency, providing basic scientific and technical research skills. The sample consists of all 1187 customers with contracts above 10,000 AUD, solicited (via email) to complete the survey instrument over seven quarters in 2002 and 2003. A significant number of customers (269) provided only their updated contact details or did not reply at all (non-response rate of 23\%), hence only 918 responses are used in this research. Nonresponse bias could not be assessed in terms of value, intent to further contract $R \& D$, and WOM, and this is one of the limitations of the study. However, there is no statistical 
significant difference in terms of customer type or value and length of the contract between customers who responded and those who did not respond. The survey instrument was completed by the project manager from the customer organization, as this person had the necessary knowledge to assess the value generated. Project managers were intimately involved in their projects and they were the main focal point for information and knowledge transfer between the service provider and the customer organization. Customers' evaluations of benefits, sacrifices, value, and their post-purchase behaviours (intention to repurchase, and WOM) were measured on a scale 1 to 10 (1-"the least satisfactorily" or "not at all" and 10-“excellent" or "almost certain"). While benefits and sacrifices are multi-item constructs, intention to repurchase and recommend were measured on a single item scale. The questionnaire also included a number of open-ended questions on value, and best and worst aspects of the collaboration/relationship. The analysis was performed in SPSS 14, Lisrel 8.71, and AMOS 6 with pooled data (the tests showed no statistical significant variability across the 7 quarters). This may represent a second limitation of the study: the assumptions of independent observations made for the static SEM may not be met for longer studies.

Table 2 Descriptive statistics

\begin{tabular}{|c|c|c|c|c|c|c|}
\hline $\begin{array}{l}\text { Variable/ } \\
\text { Indicator }\end{array}$ & Statistics & $\begin{array}{l}\text { Whole } \\
\text { sample }\end{array}$ & $\begin{array}{l}\text { Long term } \\
\text { contracts }\end{array}$ & $\begin{array}{l}\text { Short term } \\
\text { contracts }\end{array}$ & $\begin{array}{l}\text { Government } \\
\text { organizations }\end{array}$ & $\begin{array}{c}\text { Private } \\
\text { organizations }\end{array}$ \\
\hline $\begin{array}{l}\text { Contract price } \\
\text { (thousand \$) }\end{array}$ & $\begin{array}{c}\text { Mean } \\
\text { (standard } \\
\text { deviation) }\end{array}$ & $\begin{array}{r}333.8 \\
(1,316.8)\end{array}$ & $\begin{array}{r}459.2 \\
(1,448)\end{array}$ & $\begin{array}{r}177.2 \\
(1,112)\end{array}$ & $467(1,802)$ & $212.3(570.6)$ \\
\hline $\begin{array}{c}\text { Type } \\
\text { organization/ }\end{array}$ & $\begin{array}{l}\% \text { govn. vs } \\
\text { private }\end{array}$ & & $\begin{array}{l}\quad 53 \% \\
\text { government, } \\
47 \% \text { private }\end{array}$ & $\begin{array}{l}\quad 42 \% \\
\text { government, } \\
58 \% \text { private }\end{array}$ & & \\
\hline \multirow{2}{*}{$\begin{array}{l}\text { Length of } \\
\text { contract }\end{array}$} & \multirow{2}{*}{$\begin{array}{c}\text { /\% ST vs } \\
\text { LT }\end{array}$} & $44 \% \mathrm{ST}$ & & & $39 \% \mathrm{ST}$ & $49 \% \mathrm{ST}$ \\
\hline & & $56 \% \mathrm{LT}$ & & & $61 \% \mathrm{LT}$ & $51 \% \mathrm{LT}$ \\
\hline $\mathrm{N}$ & & 918 & 510 & 408 & 438 & 480 \\
\hline
\end{tabular}


The descriptive statistics highlight that private organizations spent much lower $\$$ amounts on their contracts then government organizations, even though they made up $52 \%$ of the customer base. Given the push towards less funding coming from government sources and greater proportion of funding coming from private sources, these statistics have implications for the organization's long term viability. Long term contracts were contracts that ran for more than one year.

\section{Measures and Factor Analysis Results}

Measures for the benefits and sacrifice were adapted from Kordupleski (2003) and Lapierre (2000) and used multiple items for each construct. The items used in the reflective antecedents of value and the goodness-of-fit of the measurement models are given in Table

3. Confirmatory Factor Analysis highlighted that factor unidimensionality is acceptable (Hair, Black, Babin, Anderson, and Tatham, 2006; Jöreskog and Sorbom, 1993). Table 3 shows that the three latent constructs of benefits and sacrifice have convergent validity, with reliabilities above 0.7 and item factor loadings of 0.5 or greater. Discriminant validity was assessed by testing if correlations between constructs are significantly different from unity, comparing a constrained model (with correlations $=1$ ) with the unconstrained model. The $\chi^{2}$ difference value with $\mathrm{p}<0.05$ supports the discriminant validity criterion. Also, the correlations between the constructs were lower than the reliability coefficients $(0.69$ between service and relationship benefits, -0.56 between service benefits and sacrifice, -0.7 between relationship benefits and sacrifice), suggesting that measures have discriminant validity (Crocker and Algina, 1986; Kaynak, 2003). As there are no cross-loadings between construct indicators, a two-step approach with congeneric models is most appropriate (Anderson and Gerbing, 1988). The measurement model was also assessed for 
organizational type and duration of contract with no significant differences between the groups' regression weights found. The constrained models have better goodness-of-fit statistics.

Table 3 Measures, Factor Loadings and Construct Reliabilities

\begin{tabular}{|c|c|c|c|c|c|}
\hline $\begin{array}{l}\text { Construct } \\
\text { (Eigenvalue) }\end{array}$ & Indicators & $\begin{array}{l}\text { Factor } \\
\text { Loadings* }\end{array}$ & $\begin{array}{l}\text { Cronbach } \\
\alpha / \\
\text { Composite } \\
\text { Reliability }\end{array}$ & $\begin{array}{l}\text { Goodness-of-fit } \\
\text { congeneric models }\end{array}$ & $\begin{array}{c}\text { Mean and } \\
\text { std. } \\
\text { deviation }\end{array}$ \\
\hline $\begin{array}{l}\text { A. Product } \\
\text { and Service } \\
\text { Benefits } \\
(4.23)\end{array}$ & 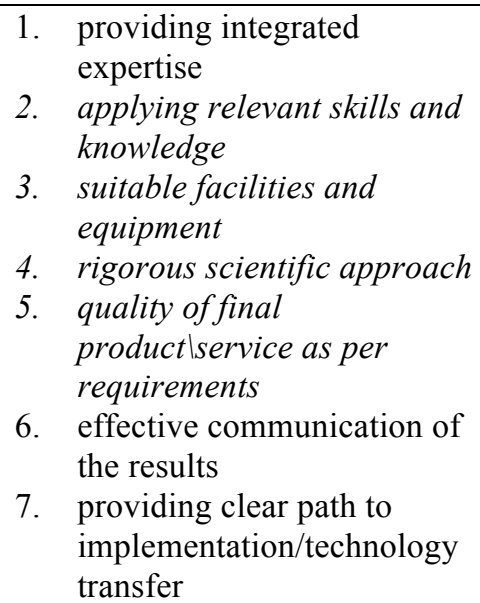 & $\begin{array}{l}0.92 \\
0.73 \\
0.74 \\
0.68 \\
0.64 \\
0.60\end{array}$ & $0.87 / 0.9$ & $\begin{array}{l}\chi^{2}=4.793 \\
(4 \mathrm{df}) \\
\text { Bollen-Stine } \mathrm{p}=0.421 \\
\text { CMINDF }=1.198 \\
\mathrm{GFI}=0.998 \\
\mathrm{AGFI}=0.990 \\
\mathrm{NFI}=0.998 \\
\mathrm{IFI}=0.999 \\
\text { RMSEA }=0.015 \\
\text { ECVI }=0.058\end{array}$ & $7.65(1.29)$ \\
\hline $\begin{array}{l}\text { B. } \\
\text { Relationship } \\
\text { Benefits } \\
(5.71)\end{array}$ & 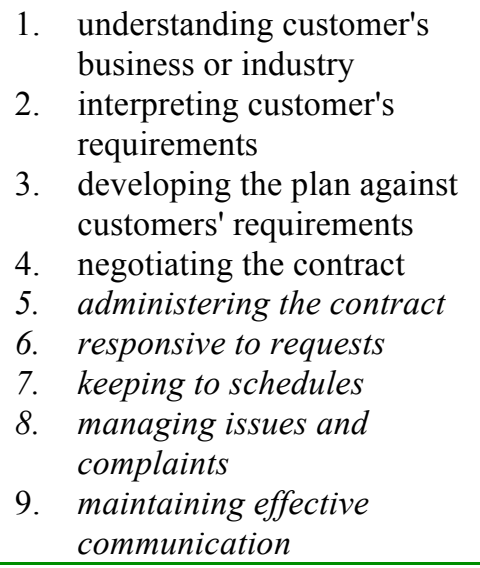 & $\begin{array}{l}0.51 \\
0.68 \\
0.72 \\
\\
0.57 \\
0.73 \\
0.55 \\
0.77 \\
0.89 \\
0.90\end{array}$ & $0.91 / 0.93$ & $\begin{array}{l}\chi^{2}=33.913 \\
(18) \\
\text { Bollen-Stine } \mathrm{p}=0.311 \\
\text { CMINDF }=1.884 \\
\text { GFI }=0.993 \\
\text { AGFI }=0.983 \\
\text { NFI }=0.995 \\
\text { IFI }=0.997 \\
\text { RMSEA }=0.031 \\
\text { ECVI }=0.09\end{array}$ & $7.09(1.58)$ \\
\hline $\begin{array}{l}\text { C. Monetary } \\
\text { Sacrifice } \\
(2.625)\end{array}$ & $\begin{array}{l}\text { 1. } \begin{array}{l}\text { information provided } \\
\text { justifying price }\end{array} \\
\text { 2. } \text { price competitive } \\
\text { 3. cost effective use of } \\
\text { customer's time planning } \\
\text { and setting up work } \\
\text { 4. } \begin{array}{l}\text { cost effective use of } \\
\text { customer's time during and } \\
\text { after the work }\end{array}\end{array}$ & $\begin{array}{l}0.53 \\
0.57 \\
0.87\end{array}$ & $0.80 / 0.85$ & $\begin{array}{l}\chi^{2}=0.276 \\
(1) \\
\text { Bollen-Stine } \mathrm{p}=0.924 \\
\text { CMINDF }=0.276 \\
\text { GFI }=1 \\
\text { AGFI }=0.998 \\
\text { NFI }=1, \text { IFI }=1 \\
\text { RMSEA }=0.000 \\
\text { ECVI }=0.02\end{array}$ & $3.25(1.56)$ \\
\hline
\end{tabular}

All factor loadings significant at 0.001 level.

Items in italic represent largest factor loadings. 
Relevant skills and knowledge is the strongest item in product and service benefits. Given the complexity of $R \& D$ projects and specialisation of the skills required, the emphasis given to this item is expected. For relationship benefits, the management of communication and issues relating to conflict have the strongest effect, followed by contract and paperwork administration. One explanation for strong loadings on these factors is that the respondent was the customer project manager where issues such as communication are critical tasks. Within monetary sacrifice the effective use of time is more valuable for customers than the contract price. This may be explained by the very nature of the relationship, which engages the customer permanently throughout project development and implementation (time-use can be considered an in-kind contribution towards the project). Also, project managers are extremely busy people and frequently managing more then one project, therefore time constraints play a major role within their normal job related activities.

\section{Structural Model Results}

As shown in the previous section, the CFA was performed before testing the full structural model, in the two step approach (Anderson and Gerbing, 1988), introducing the congeneric models in the path analysis. The results are shown in Figure 2. 
Figure 2 Structural model results (without moderators)

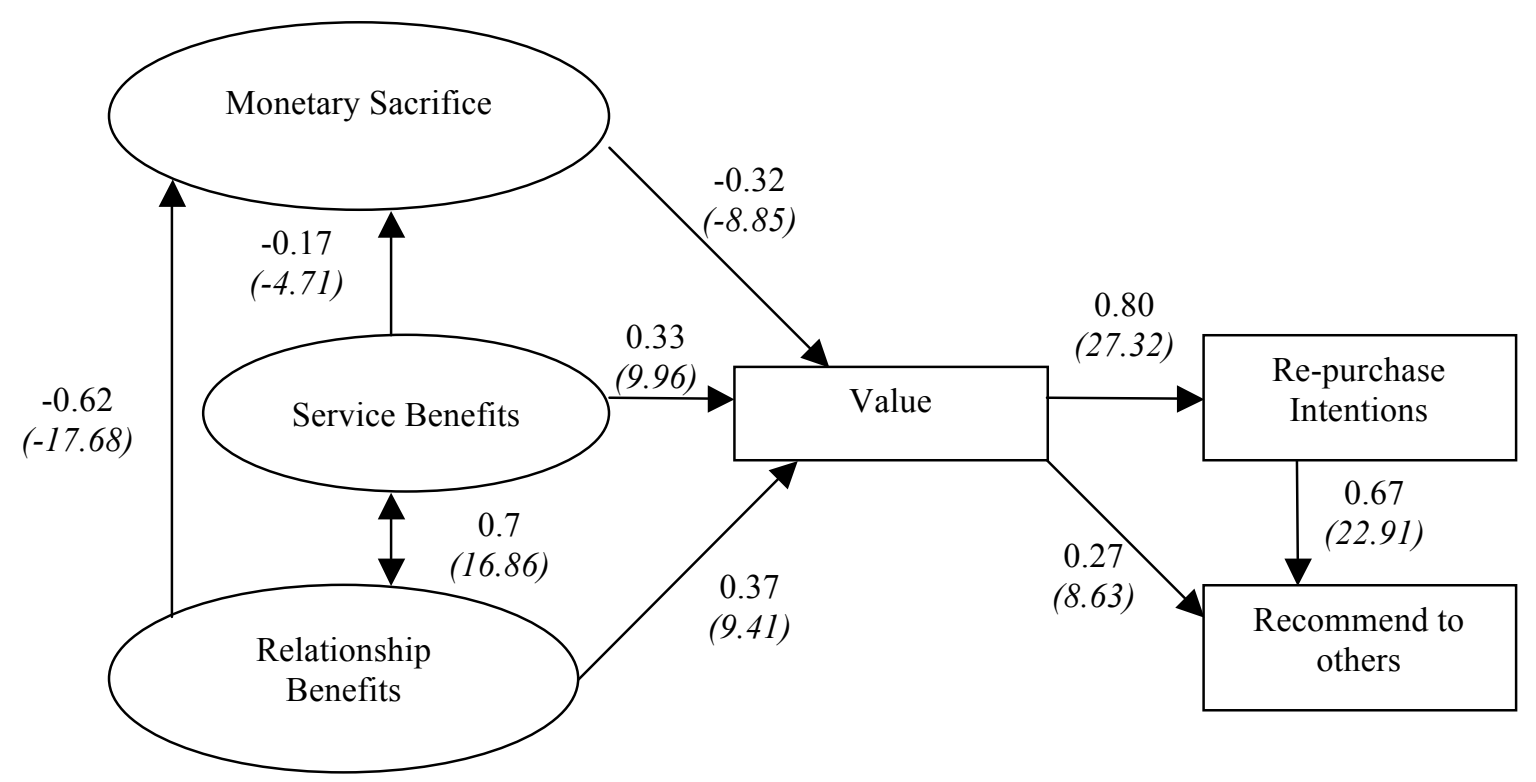

The regression weights in Figure 2 indicate the standardised coefficients and the critical values for the direct effects (McDonald and Ho, 2002). There is only one correlation included in the model, between relationship benefits and service benefits. The goodnessof-fit statistics are presented in Table 4. Fit indices indicate no inconsistency between the hypothesised model and the data, therefore accepting the model. Maximum Likelihood (ML) procedure was used in this research. As ML can give biased standard errors and incorrect test statistics in the presence of excessive skewness and/or kurtosis, multivariate normality and outliers were assessed. The analysis of residuals has shown small residual covariances $(<0.1)$. 
Table 4 Goodness-of-fit Measures for the Three Models ("No Moderators", Model for "Contract Length", and Model for "Customer Type")

\begin{tabular}{|c|c|c|c|}
\hline Goodness of fit & $\begin{array}{l}\text { Model Figure } 2 \text { - No } \\
\text { Moderators }\end{array}$ & $\begin{array}{l}\text { Moderator - Contract } \\
\text { Length }\end{array}$ & $\begin{array}{l}\text { Moderator } \\
\text { Customer Type }\end{array}$ \\
\hline$\chi^{2}(\mathrm{p}$ level $)$ & $17.347(0.004)$ & $36.429(0.000)$ & $25.68(0.007)$ \\
\hline Bollen-Stine (p level) & 0.035 & 0.015 & 0.074 \\
\hline CMINDF & 3.469 & 3.312 & 2.335 \\
\hline GFI & 0.994 & 0.987 & 0.991 \\
\hline AGFI & 0.974 & 0.957 & 0.965 \\
\hline NFI & 0.996 & 0.991 & 0.994 \\
\hline RFI & 0.988 & 0.976 & 0.984 \\
\hline IFI & 0.997 & 0.994 & 0.997 \\
\hline CFI & 0.997 & 0.994 & 0.997 \\
\hline RMSEA & 0.052 & 0.05 & 0.038 \\
\hline Standardised RMR & 0.01 & 0.017 & 0.012 \\
\hline AIC & 49.347 & 98.429 & 87.68 \\
\hline $\begin{array}{l}\text { Multivariate normality - } \\
\text { Mardia index (CR) }\end{array}$ & $39.731(61.43)$ & 44.024 (45.37) & $43.94(49.127)$ \\
\hline
\end{tabular}

The structural model highlights significant differences between government vs private customers and between LT vs ST contracts (when comparing unconstrained and constrained models, the latter is significantly different than the unconstrained model $\left(\chi^{2}\right.$ difference value $>31, \mathrm{p}<0.01$ in both cases).

All propositions, expect $4 \mathrm{a}$ and $4 \mathrm{~b}$, were supported. The relationship between Monetary Sacrifice and Service and Relationship Benefits is negative and significant. Such a relationship could occur due to the heavy loadings on the time constraints in the sacrifice construct. For example, when service and relationship benefits improve, the customer project manager perceives that they need to "spend less time" managing the project and therefore perceive less "sacrifice" needs to be given. 
Value has a positive relationship with both Service (0.33) and Relationship Benefits (0.37) and a negative relationship with Monetary Sacrifice (-0.32). Consistent with the measurement model, there is a strong correlation between Relationship and Service Benefits (0.7) indicating that any relationship benefits gained also affects service benefits.

Comparisons of model parameters for the corresponding mediator groups (defined by type of customer and length of contract) were also conducted. Table 5 shows that relationships in the model do not vary in direction ( + or -$)$, but in the magnitude of key relationships such as: between Service Benefits and Value; Relationship Benefits and Value; Sacrifice and Value; Value and WOM. Squared multiple correlation results show that the model describes government customers better than private customers, while there are minimal differences due to contract length.

Table 5 Results of the Structural Models with Moderator Variables

\begin{tabular}{|c|c|c|c|c|}
\hline \multirow[b]{2}{*}{ Propositions } & \multicolumn{2}{|c|}{ Length of Contract H8a } & \multicolumn{2}{|c|}{ Type of customer $\mathrm{H8b}$} \\
\hline & Long Term & Short Term & Government & Private \\
\hline P1 Service Benefits $\rightarrow$ Value & $0.40(8.53)$ & $0.26(3.47)$ & $0.33(6.89)$ & $0.34(3.20)$ \\
\hline $\begin{array}{l}\text { P2 Relationship Benefits } \rightarrow \\
\text { Value }\end{array}$ & $0.31(5.91)$ & $0.42(3.61)$ & $0.38(6.68)$ & $0.35(3.07)$ \\
\hline $\begin{array}{l}\text { P3 Relationship Benefits } \leftrightarrow \\
\text { Service Benefits }\end{array}$ & $0.72(12.77)$ & $0.68(11.02)$ & $0.72(11.89)$ & $0.68(11.99)$ \\
\hline $\begin{array}{l}\text { P4a Service Benefits } \rightarrow \\
\text { Monetary Sacrifice }\end{array}$ & $-0.21(-4.27)$ & $-0.12(-2.43)$ & $-0.19(-3.78)$ & $-0.15(-3.02)$ \\
\hline $\begin{array}{l}\text { P4b Relationship Benefits } \rightarrow \\
\text { Monetary Sacrifice }\end{array}$ & $-0.56(-11.47)$ & $-0.68(-13.43)$ & $-0.63(-12.65)$ & $-0.60(-12.11)$ \\
\hline $\begin{array}{l}\text { P5 Monetary Sacrifice } \rightarrow \\
\text { Value }\end{array}$ & $-0.26(-5.54)$ & $-0.35(-3.82)$ & $-0.30(-5.93)$ & $-0.33(-3.31)$ \\
\hline $\begin{array}{l}\text { P6 Value } \rightarrow \text { Re-Purchase } \\
\text { Intentions }\end{array}$ & $0.82(21.52)$ & $0.8(4.3)$ & $0.82(20.28)$ & $0.8(3.58)$ \\
\hline $\begin{array}{l}\text { P7 Value } \rightarrow \text { Recommend to } \\
\text { others }\end{array}$ & $0.42(38.10)$ & $0.24(16.78)$ & $0.43(40.8)$ & $0.2(16.61)$ \\
\hline $\begin{array}{l}\text { P8 Re-Purchase Intentions } \rightarrow \\
\text { Recommend to others }\end{array}$ & $0.52(38.10)$ & $0.70(16.78)$ & $0.55(40.8)$ & $0.71(16.61)$ \\
\hline $\begin{array}{l}\text { Squared Multiple Correlations } \\
\text { (effects on value) }\end{array}$ & 0.8 & 0.79 & 0.82 & 0.76 \\
\hline $\begin{array}{l}\text { indirect effect compared to } \\
\text { total effects }(\%)\end{array}$ & 51 & 58 & 58 & 56 \\
\hline
\end{tabular}

Results shown in italics indicate no significant differences between groups. 


\section{Discussion}

Through testing of the hypothesised structural model, we investigated the relationships between benefits, sacrifices, value, and re-purchase intention and willingness to recommend to others within the $\mathrm{R} \& \mathrm{D}$ industry, a specific part of professional $\mathrm{B} 2 \mathrm{~B}$ services. The academic and managerial implications are discussed in the following.

\subsection{Academic Implications}

All propositions, but two ( $4 \mathrm{a}$ and $4 \mathrm{~b})$ were accepted. The results show that there is a tradeoff between benefits and sacrifice when considering value within the R\&D industry. These results hold not only for the whole sample, but also for customers grouped by type of organization and type of contract. Relationship benefits has a greater influence on value then service benefits or sacrifice and is consistent with Ulaga and Eggert (2006) and differs from Wathne et al. (2001). Reasons for a stronger emphasis on relationship benefits would include the high complexity of R\&D services (and hence, the difficulty customers have in evaluating the complex scientific services offered) and the reliance of good relationships for communications. Therefore, relationship cues easily compared with other complex service providers are therefore relied upon when evaluating value delivered. This result highlights that complex service suppliers need to develop relationship competencies, rather than focus solely on technical and scientific abilities, thus improving the ability of R\&D organizations to respond to policy changes.

Another important finding is the association between value, re-purchase intentions and willingness to recommend to others. The relatively high mean scores for both 'willingness to contract for further work' and 'willingness to recommend to others' (means above 7.5 
for each customer group) indicates the strong industry position of the service provider, highly consistent with the value assessments for R\&D. Customer value has a strong positive influence (total effects 0.8 ) on WOM referrals, which is consistent with Hartline and Jones (1996). The explanation for the higher effect of value on recommendation intentions could be due to the higher risk involved in procuring $R \& D$ services compared with those in the hospitality industry (Skaates and Cova, 2005). The influence of value on customer intentions to re-purchase is consistent with previous research (see Woodall, 2003). Customers are clearly more willing to repurchase and recommend to others if the offering is viewed as "value for money" and the research organization needs to enhance its capabilities in the business area (high monetary sacrifice can significantly detract from value and high level of benefits do not necessarily guarantee customers' repurchase or WOM). Value determinants work in tandem and their interaction "sets the stage for customers' future intentions such as recommendation and repurchase" (Durvasula et al., 2004, p.323).

The large correlation between relationship and service benefits is consistent with the findings of Sweeney and Webb (2007). The total effects of benefits and sacrifice is indicated in Table 5. There are only minimal differences between indirect effects due to moderating variables, indicating that the strong correlation between relationship benefits and service benefits exist in a variety of contexts. Therefore, marketing strategies aimed at improving service and relationship benefits are valid for all situations.

Results highlighted that relationship benefits played a significantly greater role in short term contracts than in long term contracts, similar to findings by Verhoef et al. (2002). This result was unexpected as previous research shows that trust generally develops over a 
longer time period (Anderson and Weitz, 1989). An explanation for this result is that project management tasks have higher loadings compared to other items. For example, in short term contracts there is no time to deal with complaints and conflict, while on longer term contracts such issues can be handled over the course of the project so their impact is diminished. Therefore, having good complaints procedures in place at the beginning of each contract was critical for short term projects where time is of essence.

\subsection{Managerial Implications}

There are three main managerial implications that need to be highlighted:

1) Given that referrals are critical within the service industry (Salimen and Möller, 2004), evaluating which customers to include in joint communications is a key component of future marketing strategies. Results highlight that customers are likely to recommend R\&D services if value is delivered. Therefore, customers who have developed close relationships with the professional service provider and received "value" should be included in joint communication strategies such as: referencing; presenting joint papers at industry conferences; publishing joint articles in the industry media (such as newspapers, and industry journals) as well as standard academic journals; and development of case studies to use in marketing campaigns. This research assists managers in determining which customers should be approached in developing these strategies.

2) The moderating effects of organizational type show that government organizations place greater emphasis on relationship benefits when determining value compared to private organizations. An explanation for this could be the much larger monetary value spent by government contracts. Given the larger $\$$ value it is also expected that government project 
managers would be working much closer with R\&D providers to ensure contract goals are obtained. Improving relationship and interaction benefits could be achieved by integrating buying and selling centres to solve customers R\&D problems, similar to that recommended by Cova and Salle (2007) for project management services. This would require R\&D suppliers to improve the depth of interaction by assisting government customers to solve strategic problems, while at the same time implementing key account management practices.

3) Government policy towards R\&D funding is changing such that more funding needs to be sourced through private enterprises. The results from the moderating effects indicate that $R \& D$ providers focusing on these funding sources need to show private enterprise customers that they can do 'great' science maximising their service benefits, while at the same time minimising the sacrifice being made by the customer. Strategies to achieve this would include: improving brand reputation and image in relation to the science process, making customer sacrifices transparent by including time and energy commitments (and improving their time management), increasing its flexibility in providing consulting services tailored to customer, and improving relationship management skills. Improving brand reputation can be achieved through the use of referencing and referrals from existing customers.

\section{Conclusions and future research}

This research investigated the determinants of customer value within the R\&D industry. It was found that relationship benefits, service benefits and sacrifice, all had significant effects on value. Investigation of different contexts, through the use of moderating 
variables, highlighted that determinants did vary slightly, although in general could be considered equally important. Although this research was conducted for a large Australian R\&D enterprise, the results are relevant for similar highly competitive and international R\&D agencies, particularly, in developed countries from North America, Europe, and East Asia.

However, given the unique mixture of public and private initiatives and practices of the organization investigated, the results may not be entirely generalizable to other types of R\&D service providers such as universities and alliances. The results of this research contribute to our knowledge of what affects the customer value - intent to repurchase WOM pathways in the R\&D industry. Yet, there are areas that this research has highlighted needing further investigation. The moderating effects of organizational type indicate differences between government and private organizations. This categorization should be broadened to include research cooperatives/ centres, universities and other network actors such as R\&D investment brokers who influence the choice of R\&D suppliers. Secondly, the relationship between benefits and sacrifice was significant, though in a different direction from that hypothesised. It is therefore recommended that future research consider this relationship, given its likely strong influence.

\section{References}

Anderson, J.C. and Gerbing, D.W. (1988), "Structural equation modeling in practice: a review and recommended two-step approach", Psychological Bulletin, Vol.103, pp. 411-423.

Anderson, J. and Narus, J. (1999), Business Marketing Management, Prentice Hall, USA.

Anderson, E. and Weitz, B. (1989), "Determinants of continuity in conventional industrial dyads", Marketing Science, Vol. 8, No. 4, pp.310-323.

Bolton, R., Kannan, P., and Bramlett, M. (2000), "Implications of loyalty program membership and service experiences for customer retention and value", Journal of the Academy of Marketing Science, Vol. 28, No. 1, pp. 95-108. 
Buttle, F. (1998), "Word of mouth: understanding and managing referral marketing", Journal of Strategic Management, Vol. 6(3), 241-254.

Cannon, J.P. and Homburg, C. (2001), "Buyer-Supplier relationships and customer firm costs", Journal of Marketing, Vol. 65, No. January, pp. 29-43.

Caru, A. and Cugini, A. (1999), "Profitability and customer satisfaction in services", International Journal of Service Industry Management, Vol. 10, No. 2, pp. 132-157.

Cova, B. and Salle, R. (2007), "Introduction to the IMM special issue on 'Project marketing and the marketing of solutions'. A comprehensive approach to project marketing and the marketing of solutions", Industrial Marketing Management, Vol. 36, No. 2. pp. 138-146.

Crocker, L. and Algina, J. (1986), Introduction to classical and modern test theory, Harcourt, Brace, and Jovanovich, Forth Worth, Texas.

Cronin, J. and Taylor, S. (1992), "Measuring service quality: A reexamination and extension", Journal of Marketing, Vol. 56, No.3, pp. 55-68.

Dawes, P., Dowling, G. and Patterson, P. (1991), "Information Sources Used to Select Different Types of Management Consultancy Services", Asia Pacific Journal of Management, Vol. 8, Iss. 2, pp. 185-199.

Docters, R., Reopel, M., Sun, J. and Tanny, S. (2004), "Capturing the unique value of services: why pricing of services is different", The Journal of Business Strategy, Vol. 25, No. 2, pp. 23-28.

Dodds, W., Monroe, K. and Grewal, D. (1991), "Effects of price, brand and store information on buyers' product evaluations", Journal of Marketing Research, Vol. 28, No. August, pp. 307-319.

Duhan, D.F., Johnson, S.D., Wilcox, J.B., and Harrell, G.D. (1997), "Influences on Customer Use of Word-of-Mouth Recommendation Sources", Journal of the Academy of Marketing Science, Vol. 25, No. 4, pp. 283-295.

Durvasula, S., Lysonski, S., Mehta, S.C., and Tang, B.P. (2004), "Forging relationships with services: The antecedents that have an impact on behavioural outcomes in the life insurance industry", Journal of Financial Services Marketing, Vol. 8, No.4, pp.314-326.

File, K., Cermak, D. and Prince, R. (1994), "Word-of-Mouth Effects in Professional Services Behaviour", The Services Industries Journal, Vol. 14, Iss. 3, pp. 301-314.

Flint, D.J., Woodruff, R.B., and Gardial, S.F. (1997), "Customer value change in industrial marketing relationships: a call for new strategies and research", Industrial Marketing Management, Vol. 26, pp.163-175.

Fong, P., Shen, Q. and Cheng, E. (2001), "A framework for benchmarking the value management process", Benchmarketing: An International Journal, Vol. 8, No. 4, pp. 306-316.

Garrett-Jones, S., Turpin, T., Burns, P. and Diment, K. (2005), "Common purpose and divided loyalties: the risks and rewards of cross-sector collaboration for academic and government researchers", $R \& D$ Management, Vol. 35, No. 5, pp. 535-544.

Grewal, D., Gotlieb, J. and Marmorstein, H. (2000), "The moderating effect of the service context on the relationship between price and post-consumption perceptions of service quality", Journal of Business and Psychology, Vol. 14, No. 4, pp. 579-591. 
Gupta, A. and Wilemon, D. (1996), "Changing patterns in industrial R\&D management”, Journal of Product Innovation Management, Vol. 13, pp. 497-511.

Hair, J.F., Black, W.C., Babin, B.J., Anderson, R.E., and Tatham, R.L. (2006), Multivariate Data Analysis $\left(6^{\text {th }}\right.$ Ed.), Pearson Education International, New Jersey.

Håkansson, H. and Snehota, I. (2000), "The IMP Perspective, assets and liabilities of relationships", in Ford, D. (Ed.) Understanding Business Marketing and Purchasing, $3^{\text {rd }}$ Edition, Thomson Learning, pp. 35-50.

Harrison-Walker, J. (2001), "The measurement of Word-of-Mouth Communication and an investigation of service quality and customer commitment as potential antecedents", Journal of Service Research, Vol. 4, Iss. 1, pp. 60-75.

Hartline, M. and Jones, K. (1996), "Employee Performance Cues in a hotel service environment: Influence on Perceived Service Quality, Value and Word-of-Mouth Intentions", Journal of Business Research, Vol. 35, pp. 207-215.

Hirons, E., Simon, A. and Simon, C. (1998), "External customer satisfaction as a performance measure of the management of a research and development department", International Journal of Quality and Reliability Management, Vol. 15, No. 8/9, pp. 969-987.

Ismail, H. and Khatibi, A. (2004), "Study of the relationship between perception of value and price and customer satisfaction: The case of Malaysian Telecommunications Industry", Journal of American Academy of Business, Vol. 4, No. 1/2, p.309-313.

Jacob, M., Hellström, T., Adler, N. and Norrgren, F. (2000), "From sponsorship to partnership in academy-industry relations", $R \& D$ Management, Vol. 30, No.3, pp. 255-262.

Jöreskog, K.G. and Sorbom, D. (1993), LISREL 8: Structural equation modeling with the SIMPLIS command language, Chicago: Scientific Software International.

Kaynak, H. (2003), "The relationship between total quality management practices and their effects on firm performance", Journal of Operations Management, Vol. 21, pp. 405-435.

Kim, Y. and Lee, K. (2003), "Technological collaboration in the Korean electronic parts industry: patterns and key success factors", $R \& D$ Management, Vol. 33, No. 1, pp. 59-77.

Kordupleski, R. (2003), Mastering Customer Value Management, Pinnaflex Educational Resources, Inc.

Kothari, A. and Lackner, J. (2006), “A value based approach to management", Journal of Business and Industrial Marketing, Vol.21, No. 4, pp. 243-249.

Kumar, P. (2002) "The Impact of Performance, Cost, and Competitive Considerations on the Relationship between Satisfaction and Repurchase Intent in Business Markets", Journal of Service Research, Vol. 5, No. 1, pp. 55-68.

Lapierre, J. (2000), "Customer-perceived value in industrial contexts", Journal of Business and Industrial Marketing, Vol.15, No. 2-3, pp. 122-140.

Lin, C., Sher, P. and Shih, H. (2005), "Past progress and future direction in conceptualizing customer perceived value", International Journal of Service Industry Management, Vol. 16, No. 4, pp. 318-336. 
Lindgreen, A. and Wyndstra, F. (2005), "Value in business markets: What do we know? Where are we going?", Industrial Marketing Management, Vol. 34, pp. 732-748.

Mangold, W., Miller, F. and Brockway, G. (1999), "Word-of-mouth Communication in the service marketplace", The Journal of Services Marketing, Vol. 13, Iss. 1, pp. 73-89.

McDonald, R.P. and Ho, M.H. (2002), "Principles and practice in reporting structural equation analyses", Psychological Methods, Vol. 7, No.1, pp. 64-82.

Money, R., Gilly, M. and Graham, J. (1998), "Explorations of National Culture and Word-ofMouth Referral Behavior in the Purchase of Industrial Services in the United States and Japan", Journal of Marketing, Vol. 62, pp. 76-87.

Morgan, R.M. and Hunt, S.D. (1994), "The commitment-trust theory of relationship marketing", Journal of Marketing, Vol.58, No. July, pp. 20-38.

Möller, K. and Törrönen, P. (2003), "Business suppliers' value creation potential: A capabilitybased analysis“, Industrial Marketing Management, Vol. 32, pp. 109-118.

Murphy, R. (2002), "The correlative relationship between value, price \& cost", Journal of American Academy of Business, Vol. 2, No. 1, pp. 204-210.

Osawa, Y. and Yamasaki, Y. (2005), "Proposal of research and development performance indices", $R \& D$ Management, Vol. 34, No. 4, pp. 455-461.

Patterson, P., Johnston, W. and Spreng, R. (1997), "Modeling the determinants of customer satisfaction for business-to-business professional services", Journal of the Academy of Marketing Science, Vol. 25, No. 1, pp. 4-28.

Pike, S., Roos, G. and Marr, B. (2005), "Strategic management of intangible assets and value drivers in R\&D organizations", $R \& D$ Management, Vol. 35(2), 111-124.

Plewa, C. and Quester, Q. (2006), "Satisfaction with university-industry relationships: the impact of commitment, trust and championship", International Journal of Technology Transfer and Commercialisation, Vol. 5, No.1/2, pp. 79-101.

Rao, A. and Monroe, K. (1988), "The moderating effect of prior knowledge on cue utilization in product evaluations", Journal of Consumer Research, Vol.15, No. September, pp. 253-264.

Ravald, A. and Grönroos, C. (1996), “The value concept and relationship marketing”, European Journal of Marketing, Vol. 30, Iss. 2, pp. 19-30.

Salminen, R.T. and Möller, K.E. (2004), "Use of Reference Information in Bidding - A Decision Process Analysis", Journal of Marketing Management, Vol. 20, No. 1-2, February, pp. 133-155.

Salminen, R.T. and Möller, K.E. (2006), "Role of References in Business Marketing-Towards a Normative Theory of Referencing", Journal of Business-to-Business Marketing, Vol. 13, No. 1, pp. $1-51$.

Skaates, M., Tikkanen, H. and Lindblom, J. (2002), Relationships and project marketing success“, The Journal of Business \& Industrial Marketing, Vol. 17, Iss. 5, pp. 389-406.

Skaates, M.A. and Cova, B. (2005), "Marketing industrial project-related services internationally: a multi-lingual literature review", in Research on International Service Marketing: A State of the Art, Advances in International Marketing, Vol. 15, pp. 149-174. 
Skotnicki, T. (2006), “The Myth of R\&D”, Business Review Weekly, May 11-17, p. 24.

Stuart, T.E. (1998), "Network positions and propensities to collaborate: An investigation of strategic alliance formation in a high-technology industry", Administrative Science Quarterly, Vol. 43, pp. 668-698.

Sweeny, J. and Webb, D. (2007), "How functional, psychological, and social relationship benefits influence individual and firm commitment to the relationship", Journal of Business and Industrial Marketing, Vol. 22, Iss. 5.

Teas, R. and Agarwal, S. (2000), "The effects of extrinsic product cues on consumers' perceptions of quality, sacrifice, and value", Journal of the Academy of Marketing Science, Vol. 28, No. 2, pp. 278-290.

Ulaga, W. and Eggert, A. (2006), "Value-based differentiation in business relationships: gaining and sustaining key supplier status", Journal of Marketing, Vol. 70, No. January, pp. 119-136.

Verhoef, P., Franses, P. and Hoekstra, J. (2002), "The effect of relational constructs on customer referrals and number of services purchased from a multiservice provider: Does age of relationship matter?", Journal of the Academy of Marketing Science, Vol. 30, No. 3, pp. 202-216.

Voss, G., Parasuraman, A. and Grewal, D. (1998), "The roles of price, performance and expectations in determining satisfaction in service exchanges", Journal of Marketing, Vol. 62, No. October, pp. 46-61.

Walter, A., Ritter, T. and Gemünden, H. (2001), „Value-creation in buyer-seller relationships: theoretical considerations and empirical results from a supplier's perspective", Industrial Marketing Management, Vol. 30, pp. 365-377.

Wathne, K., Biong, H. and Heide, J. (2001), "Choice of supplier in embedded markets: Relationship and marketing program effects", Journal of Marketing, Vol. 65, No. 2, pp. 54-66.

Woodall, T. (2003), "Conceptualising 'Value for the customer': An attributional, structural and dispositional analysis", Academy of Marketing Science Review, No. 12, pp. 1-42.

Zeithaml, V. (1988), "Consumer perceptions of price, quality and value: A means-end model and synthesis of evidence", Journal of Marketing, Vol. 52, No. July, pp. 2-22. 